\title{
Evaluation of postoperative outcome of different techniques of lower segment caesarean section
}

\author{
Lata Rajoria, Manisha Kala, Nupur Hooja*, Smriti Bhargava, Brijesh Dadhich
}

Department of Obstetrics and Gynecology, S. M. S. Medical College, Jaipur, Rajasthan, India

Received: 07 January 2019

Accepted: 05 February 2019

\section{*Correspondence:}

Dr. Nupur Hooja,

E-mail: nupurhooja@gmail.com

Copyright: (C) the author(s), publisher and licensee Medip Academy. This is an open-access article distributed under the terms of the Creative Commons Attribution Non-Commercial License, which permits unrestricted non-commercial use, distribution, and reproduction in any medium, provided the original work is properly cited.

\begin{abstract}
Background: Caesarean section is the most commonly performed obstetric surgery. A change in the operative technique affects the postoperative outcome. The study was undertaken to study the postoperative outcome of the patient who underwent caesarean section by Pfannensteil Kerr and Misgav Ladach method of lower segment caesarean section.

Methods: It was a hospital based interventional study done in a tertiary care hospital over one year. Postoperative condition of the women was assessed after caesarean section in women with Pfannensteil Kerr and Misgav Ladach method and compared.

Results: Most cases in the Misgav Ladach method had breast fed early, had quicker return of bowel activity and earlier ambulation in comparison to the Pfannensteil Kerr method. This difference was statistically significant. Women with the Pfannensteil Kerr method had more postoperative pain, nausea and vomiting. The duration of hospital stay was less in Misgav technique.

Conclusions: Since Misgav Ladach method was a better technique than Pfannensteil Kerr, adopting it routinely would result in considerable reduction in maternal morbidity, decreased hospital stay, better patient satisfaction level and more cost effective.
\end{abstract}

Keywords: Caesarean, Misgav Ladach, Pfannensteil Kerr

\section{INTRODUCTION}

The most commonly performed surgery is caesarean section. In general, rates around the world are from about $5 \%$ to over $20 \%$ of all deliveries. ${ }^{1}$ There has been a steady increase in the caesarean section rate globally. The increase in the caesarean section rate is due to the maternal high-risk factors like severe pregnancy induced hypertension, diabetes and HIV infections. Increase detection of foetal distress and intrauterine growth restriction have also led to increased caesarean section rate. $^{2}$ Caesarean section is performed when it offers a clear benefit either to the mother or the neonate since women who undergo this procedure face increased risks of maternal morbidity compared with vaginal delivery. Caesarean section carries risk of short-term complications such as pain, haemorrhage, need of blood transfusion, injury to the intra-abdominal organs (bowel, bladder or ureters), infection and thromboembolic disease. ${ }^{3}$ Efforts of researchers are directed towards finding a safe, quick technique with good postoperative outcome, short hospital stay. The simplest and most appropriate surgical method, causing the least possible damage to the tissues, should be sought.In traditional Pfannensteil method, the dissection is done with scissors, uterus is closed in two layers and both peritoneum are sutured,with the belief 
that there is better restoration of anatomy, establishment of barrier, reduction in wound dehiscence and reducing haemorrhage. ${ }^{4}$

In the newer Misgav Ladach technique, manual separation of tissues, closure of uterus in one layer and non-suturing of the peritoneum is done. This reduces the number of stitches thereby reducing the foreign body reaction also decreasing the time of surgery and the suture material used. ${ }^{5}$ With an improved outcome, it would be easier for her to breastfeed the baby and be involved in the care of the new-born. The objective of the study was to evaluate the differences in postoperative outcomes of caesarean section by Pfannensteil Kerr and Misgav Ladach method.

\section{METHODS}

This interventional study was conducted in a tertiary care hospital.Primigravidae with live singleton term pregnancy, undergoing caesarean section and willing to be included in the study were chosen.Woman with severe anaemia, any sign of sepsis, polyhydramnios, or any medical disease were excluded. Forty women each were operated using Pfannensteil Kerr (PK) and Misgav Ladach ( ML) method. In PK technique a curved transverse supra-pubic incision in the abdominal skin, abdomen is opened by sharp dissection6 Transverse lower uterine segment incision was given, uterus repaired in double layer and peritoneum was closed. ${ }^{7}$ In ML method, abdominal wall was opened by method described by Joel-Cohen et al 8 by transverse skin incision $5 \mathrm{~cm}$ above the symphysis pubis and blunt dissection of all abdominal walls. Suturing of the uterus was done in one layer and peritoneum was left open. ${ }^{9}$

Presence of nausea, vomiting, timing of ambulation and breast feeding, return of bowel sounds and fever if any in the postoperative period was noted. Duration of hospital stay was also compared in the two groups. Data collected was statistically analyzed. $\mathrm{P}$ value $<0.05$ was taken as significant.

\section{RESULTS}

There were 40 women each in both groups. Women in the ML method group had lesser postoperative pain. The mean time of return of bowel sound in the ML group was significantly quicker than the PK group. The women could take oral intake early. Also, the mean time of ambulation in the ML group was earlier and was significantly less than PK group Table 1. In present study, the mean time of first breast feeding in the ML group was significantly earlier than the PK group. This improved the satisfaction level of the women and also increased mother infant bonding. In present study, the mean duration of hospital stay in the ML group was significantly lesser then the group with $\mathrm{PK}$, since the women were comfortable and ambulatory (Table 1). There was significant difference in the ML and $\mathrm{P}$ K group in terms of postoperative nausea, vomiting and fever, it was less in ML group (Table 2).

Table 1: Comparison of postoperative outcome in the two groups.

\begin{tabular}{|c|c|c|c|c|}
\hline \multicolumn{2}{|c|}{ Postoperative patient outcome } & Group A Mean \pm SD & Group B Mean \pm SD & Statistical significance \\
\hline \multirow{2}{*}{ VAS score } & at 2 hours & $3.7 \pm 1.3$ & $6.8 \pm 1.6$ & $<0.001(\mathrm{~S})$ \\
\hline & at 8 hours & $2.3 \pm 1$ & $4.9 \pm 1.6$ & $<0.001(\mathrm{~S})$ \\
\hline \multicolumn{2}{|c|}{ Time of first breast feeding(hours) } & $2.83 \pm 0.87$ & $3.5 \pm 0.85$ & $\mathrm{P}=0.005$ significant \\
\hline \multicolumn{2}{|c|}{ Time of return of bowel sound (hours) } & $7.4 \pm 3.3$ & $12.3 \pm 3$ & $P<0.0001$ significant \\
\hline \multicolumn{2}{|c|}{ Time of ambulation (hours) } & $18.95 \pm 8.41$ & $20.45 \pm 9.03$ & $\mathrm{P}<0.0001$ significant \\
\hline \multicolumn{2}{|c|}{ Duration of hospital stay(days) } & $5.25 \pm 0.59$ & $5.38 \pm 0.67$ & $P<0.001$ significant \\
\hline
\end{tabular}

Table 2: Comparison of postoperative morbidity in the two groups.

\begin{tabular}{|l|l|l|l|}
\hline Condition & $\begin{array}{l}\text { Group A } \\
(\mathbf{N}=40)\end{array}$ & $\begin{array}{l}\text { Group B } \\
(\mathbf{N}=40)\end{array}$ & P value \\
\hline $\begin{array}{l}\text { Nausea / } \\
\text { vomiting }\end{array}$ & $3(7.5 \%)$ & $11(27.5 \%)$ & $0.039(\mathrm{~S})$ \\
\hline Fever & $1(2.5 \%)$ & $8(20 \%)$ & $0.034(\mathrm{~S})$ \\
\hline
\end{tabular}

\section{DISCUSSION}

Women in the ML method group had lesser postoperative pain. In ML method, the abdomen is opened by blunt dissection, uterus is sutured in single layer and peritoneum is left unsutured thus, less damage is inflicted on the tissues which results in less trauma and therefore, less post-operative pain. ${ }^{10}$ NICE and WHO guidelines recommend initiating breastfeeding within one hour of birth. $^{7}$

In present study, the mean time of first breast feeding in the ML group was significantly earlier than the PK group. Sharma A et al also found that non-closure of peritoneum, as in ML method was associated with early time of first breast feeding. Postoperative pain can lead to unpleasant physiologic responses ultimately resulting in delayed breast feeding. ${ }^{11,12}$ This may cause breast engorgement and may also prolong the hospital stay. 
Decrease in post-operative pain improves mother's comfort and also the outcome of the new born infant. ${ }^{13}$

Authors observed that the mean time of return of bowel sound in the ML group was significantly quicker than the PK group. Also, the mean time of ambulation in the ML group was earlier and was significantly less than PK group. Similar to our observation, Agarwal N et al, Vitale et al also noted that time of oral intake after caesarean section were significantly earlier when peritoneum was left open though some found no significant statistical differences between the groups in regard to bowel transit time. ${ }^{6,13-15}$

Lesser duration of peritoneal cavity exposure intraoperatively in ML method and less bowel handling could be the reasons for earlier return of bowel sounds. Postoperative pain can lead to unpleasant physiologic responses including retention of secretions in respiratory system, paralytic ileus increased usage of analgesics. ${ }^{13}$ Few authors also found that ambulation was earlier after the ML operation. It has been suggested that lesser bowel handling and lesser operating time result in earlier appearance of bowel sounds, allowing early oral intake. This results in earlier ambulation. ${ }^{14,16,17}$ Authors observed postoperative nausea, vomiting and fever was significantly less in ML group. Nankali A et al and Adama $\mathrm{O}$ et al also observed that use of antibiotics was significantly lower in ML group. ${ }^{18,19}$

Since blunt opening of abdomen and uterus, single layer uterine closure and non-closure of the peritoneum during caesarean section reduces the duration of the procedure, this might benefit in terms of reduced risk of infections, fever and postoperative complications. ${ }^{13}$ Less operative time reduced the duration of exposure to anaesthesia, and hence may reduce the incidence of nausea and vomiting. Exposure of wound to external environmental contaminants also decreases that may reflect as a decrease in the incidence of febrile episodes. Also, peritoneal closure leads to the formation of peritoneal pockets where blood collects and leads to increase chances of febrile morbidity. ${ }^{20,21}$ Similar to present study, various authors also had shorter stay of women in the ML group. ${ }^{16,22}$

\section{CONCLUSION}

To conclude, less pain, earlier ambulation, breast feeding, early oral intake due to earlier return of bowel sounds made the women in the ML group more comfortable. There was lesser use of antibiotics and analgesics due to lower incidence of nausea and fever. Hence, it resulted in earlier discharge from the hospital of women in the ML group.

Funding: No funding sources Conflict of interest: None declared

Ethical approval: The study was approved by the Institutional Ethics Committee

\section{REFERENCES}

1. Bamigboye AA, Hofmeyr GJ. Non-closure of peritoneal surfaces at caesarean section--a systematic review. S Afr Med J. 2005;95(2):123-6.

2. Arias F, Bhide AG, Arulkumaran S, Damania K, Daftary SN, editors. Practical guide to high risk pregnancy and delivery. Elsevier Health Sci. 2012.

3. Grivell RM, Dodd JM. Short-and long-term outcomes after Caesarean section. Expert Rev Obstet Gynecol. 2011;6(2):205-15.

4. Deshpande H, Burute SB, Madkar CS, Dahiya P. The effect of suturing and nonsuturing of visceral and parietal peritoneum on postoperative pain in caesarean section. Int $\mathrm{J}$ Pharm Biomed Sci. 2012;3(4):164-6.

5. Mocanasu C, Anton E, Chirila R. Peritoneal suture vs. non-suture at caesarean section. Rev Med Chir Soc Med Nat Iasi. 2005;109(4):810-2.

6. Vitale SG, Marilli I, Cignini P, Padula F, D'Emidio L, Mangiafico L et al. Comparison between modified Misgav-Ladach and Pfannensteil-Kerr techniques for Caesarean section: review of literature. J Prenatal Med. 2014;8(3-4):36.

7. National Institute for Health and Clinical Excellence. CG132 Caesarean Section. Available at: http://guidance.nice.org.uk/CG132

8. Abalos E, Addo V, Brocklehurst P, El MS, Farrell B, Gray S, Hardy P, Juszczak E, Mathews JE, Masood SN, Oyarzun E. Caesarean section surgical techniques (CORONIS): a fractional, factorial, unmasked, randomised controlled trial. Lancet. 2013;382(9888):234-48.

9. Enkin MW, Wilkinson C. Single versus two layer suturing for closing the uterine incision at caesarean section. The Cochrane database of systematic reviews. 2000(2):CD000192.

10. Gencdal N, Gencdal S, Ekmekci E. Comparison of Pfannensteil Kerr and Modified Misgav Ladach Methods of Caeserean Operation. Women's Health Gynecol. 2016;2(3):1-5.

11. 11. WHO. Guideline: protecting, promoting and supporting breastfeeding in facilities providing maternity and newborn services. Geneva: World Health Organization;2017. Available at https://www.who.int/nutrition/.../guidelines/breastfee ding-facilities-maternity-newborn.

12. Sharma A, Hooja N, Shastri A, Nawal R, Bhargava S, Kala M.,Kumawat B,Manish R. Postoperative outcome of caesarean section in closure versus nonclosure of parietal peritoneum. J South Asian Feder Obstet Gynecol. 2018;10(3):182-5.

13. Cheema HK, Singh C, Mehta SS, Suri S. Closure versus Non-closure of peritoneum in Caesarean section and evaluation of post-operative pain: A hospital-based study. Int J Sci Study. 2014;2(9):8992.

14. Agarwal N, Agarwal BK. Effect of Non-Closure of Peritoneum on Outcome of Caesarean Section ${ }^{-} \mathrm{A}$ 
Prospective Randomized Control Study Int J Sci Res. 2015;4(6).

15. Moradan S, Mirmohammadkhani M. Comparison of Misgav-Ladach and Pfannenstiel-Kerr Techniques for Cesarean Section: A Randomized Controlled Trial Study. Middle East Journal of Rehabilitation and Health. 2016;3(4).

16. Hudić I, Bujold E, Fatušić Z, Skokić F, Latifagić A, Kapidžić M, Fatušić J. The Misgav-Ladach method of Caesarean section: a step forward in operative technique in obstetrics. Arch Gynecol Obstet. 2012;286(5):1141-6.

17. Şahin N, Genc M, Turan GA, Kasap E, Güçlü S. A comparison of 2 Caesarean section methods, modified Misgav-Ladach and Pfannensteil-Kerr: A randomized controlled study. Advances in clinical and experimental medicine: official organ Wroclaw Medical University. 2018.

18. Nankali A, Farajzadeh F, Rezaei M, Malekkhosravi S, Daeichin S. Comparison of the Outcomes of Traditional and Mis-gav-Ladach Techniques in Caesarean Section. J Biol Today's World. 2014;3(2):44-8.

19. Adama O, Barnabé YR, Gueswendé KF, Sibraogo K, Paul KD, Alexi SY. Prognosis of Misgav-Ladach
Caesarean Sections in an African Environment: Case of the Banfora Regional Hospital in Burkina Faso about 110 Cases. Open J Obstet Gynecol. 2017;7(09):1006.

20. Tabasi Z, Mahdian M, Abedzadeh-Kalahroudi M. Closure or non-closure of peritoneum in Caesarean section:outcomes of shortterm complications.Arch Trauma Res. 2013:1(4):176-9.

21. Noreen S, Alam M, Khan WY, Sultana R, Gul S. A comparison of peritoneal closure with non-closure for short term morbidity in emergency lower segment Caesarean section KJMS. 2015;8(1):76-9.

22. Jindal M, Gupta M, Goraya SP, Matreja PS. Single Layer Versus Double Layer Closure of Uterus during Caesarean Section-A Prospective Study in Index and Subsequent Pregnancy. Int Arch BioMed Clinic Res. 2017;3(1):50-3.

Cite this article as: Rajoria L, Kala M, Hooja N, Bhargava S, Dadhich B. Evaluation of postoperative outcome of different techniques of lower segment caesarean section. Int J Reprod Contracept Obstet Gynecol 2019;8:951-954. 